\title{
A new atraumatic temporomandibular joint dislocation reduction technique. Note
}

\section{preview}

Uma nova técnica de redução da luxação da articulação temporomandibular atraumática. Nota

prévia

Una nueva técnica atraumática de reducción de la dislocación de la articulación

temporomandibular. Nota previa

Received: 12/14/2021 | Reviewed: 12/19/2021 | Accept: 12/26/2021| Published: 01/04/2022

Gustavo Silva Pelissaro

ORCID: https://orcid.org/0000-0003-3475-6001

Universidade Federal do Mato Grosso do Sul, Brasil

E-mail: gustavopelissaro@ hotmail.com

Ellen Cristina Gaetti Jardim

ORCID: https://orcid.org/0000-0003-2471-465X

Universidade Federal do Mato Grosso do Sul, Brasil

E-mail: ellen.jardim@ufms.br

Jose Carlos Garcia de Mendonça

ORCID: https://orcid.org/0000-0003-3217-872X

Universidade Federal do Mato Grosso do Sul, Brasil

E-mail: jose.mendonca@ufms.br

Janayna Gomes Paiva-Oliveira

ORCID: https://orcid.org/0000-0003-2090-2872

Universidade Federal do Mato Grosso do Sul, Brasil

E-mail: janaynajgpaivaoliveira@gmail.com

Muryllo Eduardo Sales dos Santos

ORCID: https://orcid.org/0000-0001-8517-4154 Universidade Federal do Mato Grosso do Sul, Brasil

E-mail: muryllosales@gmail.com

Maisa de Oliveira Aguillera

ORCID: https://orcid.org/ 0000-0003-0055-6984 Universidade Federal do Mato Grosso do Sul, Brasil

E-mail: maisa.aguillera@live.com

Francielly Thomas Figueiredo

ORCID: https://orcid.org/0000-0003-0196-1172 Universidade Federal do Mato Grosso do Sul, Brasil

E-mail: francielly.thomas@ufms.br

\begin{abstract}
In light of the new coronavirus pandemic, emotional temporomandibular joint disorders have become more common. As a result, abnormal wear of the bones and cartilages in this joint may favor the triggering of temporomandibular dislocations. This technical note describes a new atraumatic method for reducing temporomandibular dislocation, with advantages over the traditional Nelaton maneuver. The corresponding author states that he has been using this technique for over 20 years in Brazilian public hospitals with absolute success. The note is original and has never been submitted, in full or in part, to any journal. This work aims to present an innovative technique, easy to perform and free of cost, in order to facilitate the reduction of temporomandibular dislocations.
\end{abstract}

Keywords: Temporomandibular joint; Joint dislocations; Temporomandibular joint disorders.

\footnotetext{
Resumo

À luz da nova pandemia de coronavírus, distúrbios emocionais da articulação temporomandibular tornaram-se mais comuns. Como resultado, o desgaste anormal dos ossos e cartilagens dessa articulação pode favorecer o desencadeamento de luxações temporomandibulares. Esta nota técnica descreve um novo método atraumático para redução da luxação temporomandibular, com vantagens sobre a tradicional manobra de Nelaton. O autor correspondente afirma que utiliza essa técnica há mais de 20 anos em hospitais públicos brasileiros com sucesso absoluto. A nota é original e nunca foi submetida, no todo ou em parte, a nenhum periódico. Este trabalho tem como objetivo apresentar uma técnica inovadora, de fácil execução e gratuita, a fim de facilitar a redução das luxações temporomandibulares.
} 
Palavras-chave: Articulação temporomandibular; Luxações articulares; Transtornos da articulação temporomandibular.

\section{Resumen}

A la luz de la nueva pandemia de coronavirus, los trastornos emocionales de la articulación temporomandibular se han vuelto más comunes. Como resultado, el desgaste anormal de los huesos Y cartílagos de esta articulación puede favorecer la activación de dislocaciones temporomandibulares. Esta nota técnica describe un nuevo método atraumático para reducir la luxación temporomandibular, con ventajas sobre la maniobra tradicional de Nelaton. El autor correspondiente afirma que ha estado utilizando esta técnica durante más de 20 años en los hospitales públicos brasileños con absoluto éxito. La nota es original Y nunca ha sido enviada, total o parcialmente, a ninguna revista. Este trabajo tiene como objetivo presentar una técnica innovadora, fácil de realizar Y gratuita, con el fin de facilitar la reducción de las luxaciones temporomandibulares.

Palabras clave: Articulación temporomandibular; Luxaciones articulares; Trastornos de la articulación temporomandibular.

\section{Introduction}

The temporomandibular joint (TMJ) is a peculiar joint: highly specialized, with wide mobility and complex, articulating the head of the mandible, the joint cavity and the joint eminence, the articular disc, the retrodiscal tissues, the synovial membrane and the capsule. It is innervated by branches of the auriculotemporal, masseteric and posterior deep temporal nerves, branches of the mandibular nerve and irrigated by branches of the external carotid artery (Okeson, 2019; Hamza et al., 2020; Lima et al., 2020).

Temporomandibular joint dislocation is a condition in which the head of the mandible moves out of its physiological position, remaining ahead of the articular eminence of the temporal bone (Gay-Escoda, 1987) (Fig. 1). It can be caused by trauma, anatomical variations, ligamentous extension, or muscle hypermobility (Luyk \& Larsen, 1989; Freitas et al., 2006; Akinbami, 2011).

The condyle is displaced out of the joint cavity and normally positioned towards the anterior region of the joint eminence (Martín et al., 2009). The absence of mouth closure, chin protrusion, masticatory muscle tension and spasms, drooling, difficulty in speech and pain in the TMJ region are characteristic (Myrhaug et al., 1951). In the presence of one or more etiological factors, dislocation can be triggered by excessive mouth opening when yawning, smiling or by manipulation of the jaw during dental treatments (Pinto et al., 2012; Castro et al., 2013).

At the moment of dislocation, the pain stimulates the protruding muscles to pull the condyle forward; while the levator muscles tend to pull the jaw back. These two opposing forces generate a vectorial resultant that keeps the condyle elevated and held in front of the articular eminence (Pereira, 2007).

An interesting aspect of dislocations is the potential for reversibility through external, manual or surgical intervention, in order to correctly reposition the condyle to the articular fossa performing the inverse movement of the dislocation (Bernardino Júnior et al., 2006).

Thus, it is shown that the contribution of conservative treatments for reducing TMJ dislocation is relevant in acute dislocations, and can also act as a supporting method to surgical techniques for reducing recurrent dislocations (Ungor et al., 2010; Machon et al., 2009). The success of the treatment will depend on a correct and accurate diagnosis, the experience of the professional and the technique used, whether surgical or not (Vilar et al, 2020; Pereira et al., 2021). 
Figure 1 - Dislocation of the temporomandibular joint. Dislocation of the head of the mandible during temporomandibular dislocation.

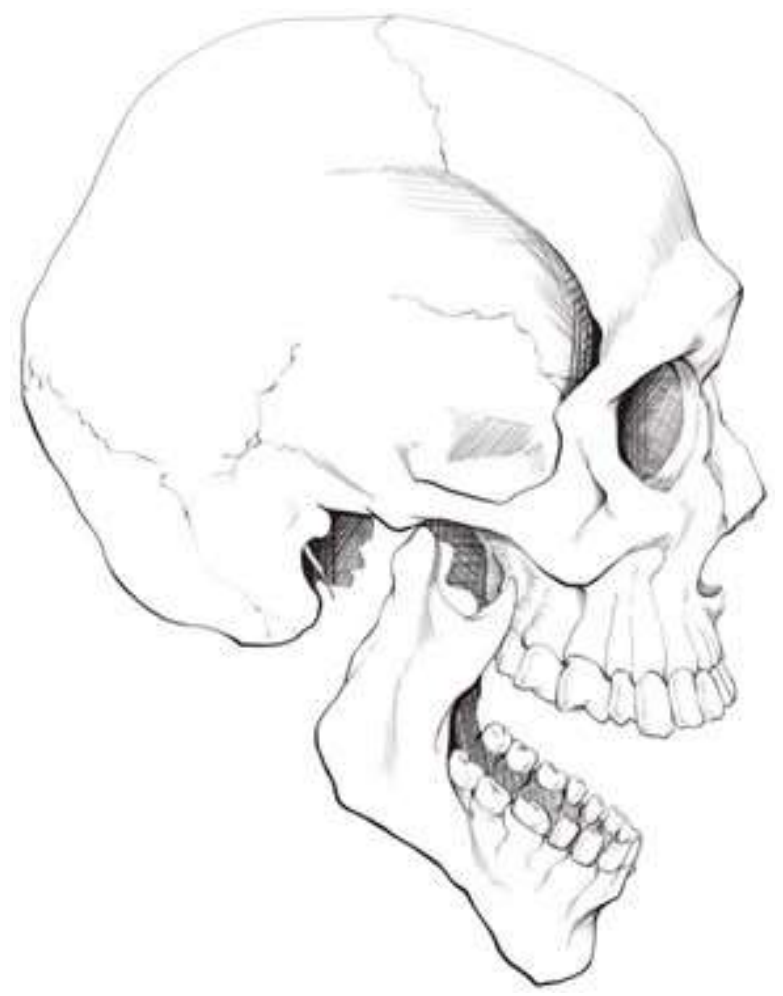

Source: Authors.

The most widespread conservative technique for reducing TMJ dislocation is the Nelaton maneuver, as described by Charlier \& Benmoussa (2019).

This paper aims to describe an alternative conservative maneuver as an option to those usually recommended, aiming at lesser application of force and ease of execution in a hospital bed, resulting in greater patient comfort.

\section{Metodology}

After the diagnosis of TMJ dislocation, the first step to perform the reduction is to place the patient in a sitting or supine position, with the posterior region of the head supported by a rigid structure. Then, the anatomical structures are located, placing the index finger of the right hand inside the oral cavity, in the most prominent region of the coronoid process of the mandible, which will be anterior and rotated clockwise. The left hand will be placed externally under the chin, supporting the entire anterior region of the jaw. For the reduction movement, the finger positioned on the coronoid must exert force in the posterior direction, while the other hand, under the chin, performs the jaw elevation movement. The two movements for reduction must be performed simultaneously and on one side only. If the TMJ dislocation is bilateral, after reducing one side, repeat the same procedure on the contralateral side (Gay-Escoda, 1987).

Nelaton's technique for reducing dislocations requires pressure downwards bilaterally in the posterior region of the occlusal plane of the mandible, intraorally, which takes the greater application of force in the opposite direction to the resistance induced by the mandible elevator muscles, to nullify it. Then, keeping this force vector down, the jaw is shifted back (Jamain, 1859) (Fig. 2). 
Figure 2 - Nelaton's maneuver. Hand positioning during the traditional Nelaton maneuver.

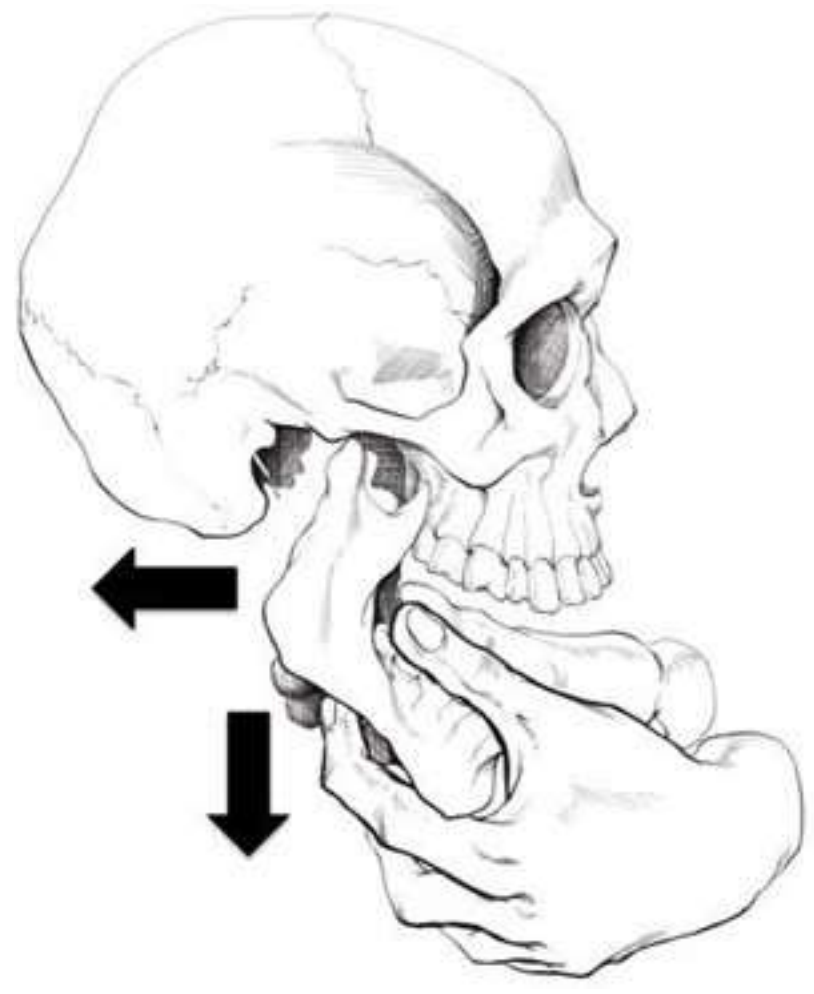

Source: Authors.

On the other hand, the technique here described shows that the force vectors applied to the mandible tend to follow the direction of muscular resistance, which is upwards and backward, using part of this force to help with reduction. Furthermore, by using two simultaneous points of force application, one in the mental region and the other in the coronoid process, we create a first-order lever where the fulcrum is the coronoid process of the mandible (Fig. 3).

Figure 3-New TMJ dislocation reduction technique. Hand placement and direction offorce proposed by this technical note.

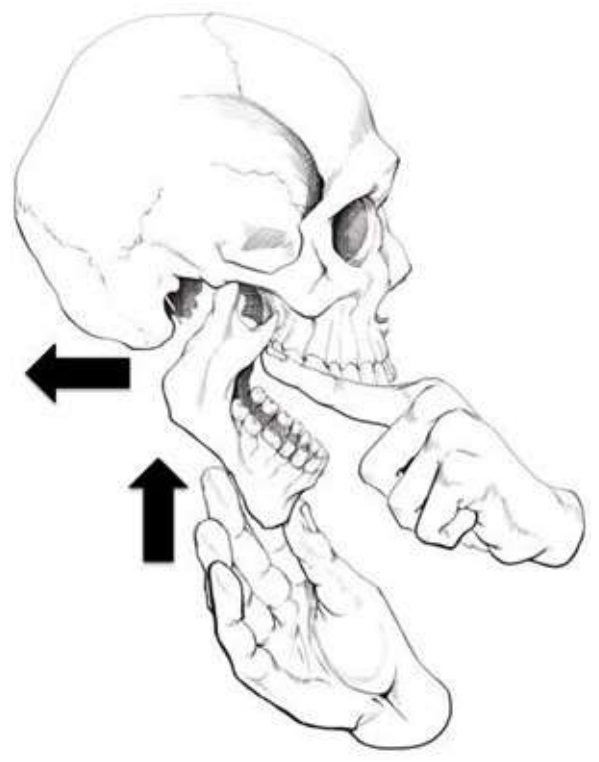

Source: Authors. 
Thus, the force used to overcome the articular eminence and bring the mandible to its physiological position is potentiated by the lever. Therefore, the great differential of this technique is the use, and not the nullification, of muscular endurance forces, using physical principles of vectors and lever, resulting in less use of force to reduce the dislocation.

Other advantages of this maneuver are the possibility of its reproduction in bedridden patients and the protection of the operator's fingers, which are not in the occlusal line during reduction (Fig. 4).

Figure 4 - Patient in horizontal decubitus. Execution of the new technique even in patients in the horizontal decubitus position.

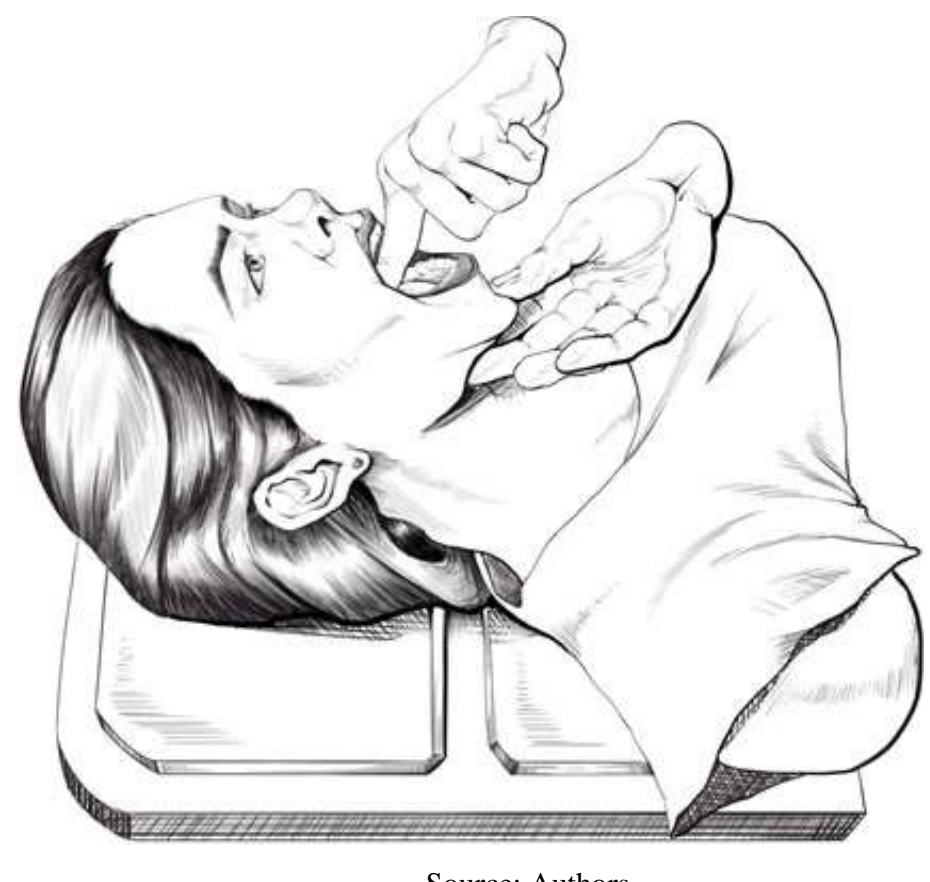

Source: Authors.

\section{Results and Final Considerations}

To perform the conventional technique for reducing TMJ dislocation, it is essential that the patient is in an anatomical position, standing or sitting, for a correct application of force vectors. At this moment, another important advantage of the technique described in this work is presented, which is the possibility of its application in patients in horizontal decubitus position, a condition that practically makes the use of the conventional Nelaton technique unfeasible due to the difficulty in applying the vertical force vector in the mandible with the bedridden patient.

Another condition associated with the conventional technique is the need to protect the operator's thumbs with gauze or silicone or rubber devices, as they are on the occlusal plane of the mandible, and can be injured by teeth or by the actual occlusion of the mandible. continuous reduction of ATM.

In the presented technique, the index finger is the only one that penetrates the oral cavity to push the coronoid process to the posterior region, and as this structure is located laterally to the occlusal plane, there is no risk of injury to the operator.

The purpose of this technical note is to contribute with one more option among the varieties of conservative techniques for reducing TMJ dislocation. The choice of method is up to the professional.

TMJ dislocation is a reality. The technique described here will also facilitate the reduction of dislocation by the clinician with greater ease and safety compared to the traditional Nelaton's technique. 


\section{References}

Akinbami, B. O. (2011). Evaluation of the mechanism and principles of management of temporomandibular joint dislocation. Systematic review of literature and a proposed new classification of temporomandibular joint dislocation. Head \& Face Medicine. 7(1):1-9. DOI: 10.1186/1746-160X-7-10.

Bernardino Junior, R., Teixeira, M., Goulart, L., Guedes, L., Costa, E. (2006). Avaliação de técnica alternativa aplicada ao tratamento imediato de luxação espontânea da articulação temporomandibular. Bioscience Journal. 22(3): 105- 111.

Castro, C. H. S., Azevedo, R. A., Maciel, A. S., Rocha, G. M. (2013). Fratura de miniplaca em tratamento de luxação de ATM - Que conduta tomar? Archives of Health Investigation. 2(5):54-58.

Charlier, P., Benmoussa, N. (2019). Should we call the maneuver of dislocation reduction of the jaw" Egyptian maneuver" instead of" Nélaton maneuver"? Journal of Stomatology and Oral and Maxillofacial Surgery. 120(6):608-610. DOI: 10.1016/j.jormas.2019.05.002

Freitas, R. (2006). Tratado de Cirurgia Bucomaxilofacial. 1ª ed. São Paulo, Editora Santos, pp. 571 - 606.

Gay-Escoda, C. 1987. Eminectomy associated with redirectioning of the temporal muscle for treatment of recurrent TMJ dislocation. Journal of CranioMaxillofacial Surgery. 15:355-358. DOI: 10.1016/s1010-5182(87)80082-3.

Hamza, A., Gidley, P. W., Learned, K. O., Hanna, E. Y., \& Bell, D. (2020). Uncommon tumors of temporomandibular joint: An institutional experience and review. Head \& neck, 42(8), 1859-1873.

Jamain, A. (1859). Manuel de pathologie et de clinique chirurgicales (Vol. 2). Germer-Baillière.

Lima, L., Silva, F., Monteiro, M., Junior, G. (2020). Depressão e ansiedade e a associação com disfunções temporomandibulares - revisão de literatura. Research, Society and Development. 9(7), e579974540.

Luyk, N. H., Larsen, P. E. (1989). The diagnosis and treatment of the dislocated mandible. The American Journal of Emergency Medicine. 7(3):329-335. DOI: $10.1016 / 0735-6757(89) 90181-2$.

Machon, V., Abramowicz, S., Paska, J., Dolwick, M. F. (2009). Autologous blood injection for the treatment of chronic recurrent temporomandibular joint dislocation. Journal of Oral and Maxillofacial Surgery. 67(1):114-119.

Myrhaug, H. (1951). A New method of operation for habitual dislocation of the mandible: review of former methods of treatment.

Acta Odontologica Scandinavica. 9: 247-261.

Okeson, J. P. (2019). Management of temporomandibular disorders and occlusion-E-book. Elsevier Health Sciences.

Pereira, A. M. (2007). Luxação recidivante do côndilo mandibular: revisão de literatura. Revista de Odontologia Clínica Científica. 6(2): 117-122.

Pereira, J. V. C., Campos, G. S., de Paula, D. M. (2021). Abordagem cirúrgica em desordens da Articulação Temporomandibular (ATM): uma revisão de literature. Research, Society and Development. 10(13): e568101321711.

Pinto, L. A. P. F., Guimarães, M. A. A., Coutinho, M. A. (2012). Eminectomia: tratamento para a luxação da articulação temporomandibular recidivante. Revista de Cirurgia e Traumatologia BucoMaxilo-Facial. 12(1):53-60.

Ungor, C., Kerem, T. A., Fatih, T., Burak, C., Ezher, H. D., Emre, T., Figen, C. S. (2010). Long-term efficacy of botulinum toxin type a for the treatment of habitual dislocation of the temporomandibular joint. British Journal of Oral and Maxillofacial Surgery. 48:281- 4.

Vilar, E. G. S., Pereira, E. S. B. M., Eleutério, R. G., Trazzi, B. F. M., da Silva, W. S. (2020). Indicações cirúrgicas de deslocamento do disco articular da articulação temporomandibular. Brazilian Journal of Health Review. 3(5): 13790-13809.

\section{Conflict of Interest}

There is no Conflicts of Interest.

\section{Ethics statement/confirmation of patient permission}

Ethics approval is not required. There is no need patient permission or consent for this technical note.

\section{Acknowledgment}

This work was carried out with support from the Federal University of Mato Grosso do Sul Foundation. UFMS/MEC - Brazil. The authors would like to thank Rafaela Cristine Werlang, a telecommunications engineer and friend, for all the help offered in carrying out this work. 